\title{
THE SIGNIFICANCE OF FRACTIONAL INTERESTS IN LISTED PROPERTY TRUST PORTFOLIOS
}

\author{
GRAEME NEWELL and TAN YEN KENG \\ University of Western Sydney
}

\section{ABSTRACT}

Fractional interests in commercial property have taken on increased importance as institutional investors seek to manage risk in their property portfolios. By assessing the ownership arrangements of over 8,000 commercial properties, the level of fractional interests in listed property trust (LPT) property portfolios in Australia over 1991-2004 is assessed. Significant increases in the level of fractional interests (both by number and value of properties) have been evident in the last five years; particularly reflecting increased levels of co-owned international property in LPT portfolios and the acquisition of local landmark office and retail properties via fractional interests. Retail and office property in a 50\%:50\% co-ownership arrangement is the most dominant local fractional interest structure, with international properties more likely to involve more than a 50\% fractional interest by the LPT.

Keywords: Fractional interests, co-ownership, LPTs, ownership structure, property type, risk management

\section{INTRODUCTION}

The cost of many major commercial property assets now often exceeds prudent investment bounds for many property investors. As such, fractional interests or coownership in commercial property have taken on increased importance as institutional investors seek to manage single-asset risk in their property portfolios.

A fractional interest is defined as a divided or individual right in property that represents less than the whole. This fractional interest co-ownership arrangement enables investors to achieve diversification, portfolio flexibility, facilitate incremental growth of property portfolios and accessing landmark assets that would otherwise be excluded from their property portfolios (Fife and Newell, 1995). Similarly, it expands the potential investment opportunities for property investors (eg: international property investors) without creating unacceptable new risks (Hess and Liang, 2004).

However, fractional interests also have the potential for reduced liquidity and a lack of absolute management control over the direction of the property investment, and the 
resulting potential for discounts to these fractional interests. This has seen general acceptance of a 50\%:50\% fractional interest co-ownership arrangement to balance the issues of affordability and the need for management control (Hess and Liang, 2004).

Evidence of the increased acceptance of fractional interests is shown in their significant increase in usage in US REIT property portfolios over 1998-2002; particularly for high value properties (Hess and Liang, 2004). Fractional interest properties were also seen to outperform 100\%-owned properties in the US over 1990-2004; particularly for office and industrial property (Ludgin and Ingall, 2004).

Much of the research on fractional interests has focused on the valuation of fractional interests; particularly the determination of fractional interest discounts. Specific aspects include the compatibility of the co-owners (Donaldson, 1994; Hanford, 1989), impact of number of co-owners (Humphrey and Humphrey, 1997), terms of the co-ownership agreement (Thompson and Dagbjartsson, 1994) and discounting methodologies (Wiggins and Rosenberg, 2001). In Australia, current procedures for valuing fractional interests have been investigated (Fife and Newell, 1995) and the key factors influencing the valuation of fractional interests identified (Fife, 2003); these factors including underlying asset quality, control and terms of the co-ownership agreement; ownership structure and liquidity were seen to be less critical factors.

While the increased incidence of fractional interests in US REIT portfolios has been assessed (Hess and Liang, 2004), the property investment stature of listed property trusts (LPTs) in Australia provides an opportunity for assessing the significance of fractional interests as part of LPT property investment strategies. In particular, LPTs have been the most successful indirect property investment vehicle in Australia in recent years, with LPTs performing strongly compared to the other major asset classes over the last ten years (see Table 1). At December 2004, the LPT sector had total assets of over $\$ 100$ billion, comprising over 1500 institutional-grade properties in diversified and sector-specific portfolios (Property Investment Research, 2004b). LPTs account for over $\$ 77.8$ billion in market capitalisation, representing over $8 \%$ of the total Australian stockmarket capitalisation (UBS, 2005). 
Table 1: Asset class performance analysis: June $2004^{(1)}$

\begin{tabular}{|l|cccc|}
\hline \multirow{2}{*}{ Asset class } & \multicolumn{4}{|c|}{ Average annual return (\%) } \\
& $\mathbf{1 Y}$ & $\mathbf{3 Y}$ & $\mathbf{5 Y}$ & $\mathbf{1 0 Y}$ \\
\hline Direct property & $10.91 \%(3)$ & $10.43 \%(2)$ & $10.63 \%(2)$ & $10.07 \%(2)$ \\
Office & $7.43 \%$ & $7.63 \%$ & $8.78 \%$ & $8.81 \%$ \\
Retail & $13.87 \%$ & $12.94 \%$ & $12.24 \%$ & $10.98 \%$ \\
Industrial & $12.98 \%$ & $12.94 \%$ & $12.80 \%$ & $13.83 \%$ \\
& & & & \\
LPTs & $\mathbf{1 7 . 2 2 \% ( 2 )}$ & $\mathbf{1 4 . 8 2} \%(\mathbf{1})$ & $\mathbf{1 4 . 0 8} \%(\mathbf{1})$ & $\mathbf{1 2 . 2 8 \% ( 1 )}$ \\
Office & $5.90 \%$ & $7.50 \%$ & $9.40 \%$ & $9.10 \%$ \\
Retail & $24.40 \%$ & $18.00 \%$ & $15.40 \%$ & $14.20 \%$ \\
Industrial & $14.30 \%$ & $17.20 \%$ & $15.90 \%$ & $12.90 \%$ \\
Diversified & $15.10 \%$ & $15.10 \%$ & $14.70 \%$ & $12.30 \%$ \\
& & & & \\
Shares & $22.37 \%(1)$ & $4.93 \%(4)$ & $7.41 \%(3)$ & $10.02 \%(3)$ \\
& \multicolumn{5}{|c}{} \\
Bonds & $1.86 \%(4)$ & $5.20 \%(3)$ & $5.61 \%(4)$ & $7.85 \%(4)$ \\
\hline
\end{tabular}

(1) Ranks of major asset classes given in brackets Sources: PCA (2004), UBS (2005)

Currently, LPTs account for approximately $8 \%$ of institutional asset allocations and account for $49 \%$ of all institutional-grade property in Australia (Garing et al, 2004). LPT and stockmarket performance in Australia are correlated $(r=.63$ over 1985-2004) (Property Council of Australia, 2004) and it has been shown that there is no long-term market integration between LPTs and the stockmarket (Wilson and Okunev, 1996, 1999; Wilson et al, 1998). This evidence of market segmentation suggests that there are diversification benefits from including LPTs in an investment portfolio, particularly in conditions of increased stockmarket volatility (Newell and Acheampong, 2001), with both diversified and sector-specific strategies seen to be equally effective for LPT portfolio diversification (Newell and Tan, 2003).

As such, the purpose of this paper is to assess the level of fractional interests amongst the LPT property portfolios over 1991-2004, involving the assessment of the ownership arrangements for over 8,000 commercial properties over this 14-year period. Issues to be assessed include whether the incidence of fractional interests has increased in recent years, what ownership structures are used for these fractional interests, what property types are included as fractional interests, and has the increased investment in international property seen the increased use of fractional interests as part of the risk management strategy of LPTs. 


\section{DATA AND METHODOLOGY}

Details of the LPT property portfolios over the fourteen year period of 1991-2004 were obtained from PIR (2004a) on an annual basis. This involved the assessment of 8,158 commercial properties in 492 LPT portfolios, worth over $\$ 453$ billion over this period. Data entry, the establishment of this individual LPT property portfolio database and quality assurance procedures took in excess of 150 hours to develop. Specific details obtained per property were:

- ownership structure: $100 \%$ or fractional interest

- type of property

- value of property

- location of property (local or international).

Fractional interests were identified, with analyses done both by value and number of properties. For benchmarking purposes, equivalent features for LPT properties with $100 \%$ ownership were also obtained.

\section{RESULTS AND DISCUSSION}

\section{LPT fractional interest profile}

Table 2 presents the LPT fractional interest profile over 1991-2004. Aggregated over this 14 -year period, fractional interests accounted for $23.7 \%$ by value of properties and $14.3 \%$ by number of properties in the total LPT property portfolio. In total, this represents over $\$ 107$ billion and 1,164 commercial properties as fractional interests in these LPT property portfolios ${ }^{1}$, which comprised 8,158 properties valued at $\$ 453$ billion over this fourteen year period.

\footnotetext{
${ }^{1}$ As the fractional interest profile was assessed at the end of each year, properties held as fractional interests over a number of years are included each year for the purposes of this analysis.
} 
Table 2: LPT fractional interest profile: 1991-2004

\begin{tabular}{|c|c|c|c|c|c|c|c|}
\hline \multirow[b]{2}{*}{ Year } & \multirow[b]{2}{*}{$\begin{array}{l}\text { Number } \\
\text { of LPTs }\end{array}$} & \multirow[b]{2}{*}{$\begin{array}{c}\text { Value of } \\
\text { total LPT } \\
\text { portfolio }\end{array}$} & \multirow[b]{2}{*}{$\begin{array}{c}\text { Number of } \\
\text { properties } \\
\text { in LPT } \\
\text { portfolio }\end{array}$} & \multicolumn{4}{|c|}{ LPT fractional interest portfolio } \\
\hline & & & & Value & $\begin{array}{l}\text { Percentage } \\
\text { by value }^{(1)}\end{array}$ & $\begin{array}{c}\begin{array}{c}\text { Number } \\
\text { of }\end{array} \\
\text { properties }\end{array}$ & $\begin{array}{c}\text { Percentage } \\
\text { by number } \\
\text { of } \\
\text { properties }^{(2)}\end{array}$ \\
\hline 1991 & 16 & $\$ 7.50 \mathrm{~B}$ & 137 & $\$ 1.27 \mathrm{~B}$ & $16.9 \%$ & 19 & $13.9 \%$ \\
\hline 1992 & 23 & $\$ 8.20 \mathrm{~B}$ & 192 & \$1.64B & $20.1 \%$ & 25 & $13.0 \%$ \\
\hline 1993 & 28 & $\$ 9.00 \mathrm{~B}$ & 219 & $\$ 2.51 \mathrm{~B}$ & $27.9 \%$ & 34 & $15.5 \%$ \\
\hline 1994 & 34 & $\$ 12.39 \mathrm{~B}$ & 256 & $\$ 3.51 \mathrm{~B}$ & $28.3 \%$ & 44 & $17.2 \%$ \\
\hline 1995 & 36 & $\$ 13.72 \mathrm{~B}$ & 303 & $\$ 4.09 \mathrm{~B}$ & $29.8 \%$ & 49 & $16.2 \%$ \\
\hline 1996 & 40 & $\$ 18.97 \mathrm{~B}$ & 391 & $\$ 4.82 \mathrm{~B}$ & $25.4 \%$ & 55 & $14.1 \%$ \\
\hline 1997 & 50 & $\$ 25.29 \mathrm{~B}$ & 537 & $\$ 6.22 \mathrm{~B}$ & $24.6 \%$ & 63 & $11.7 \%$ \\
\hline 1998 & 50 & $\$ 31.55 \mathrm{~B}$ & 649 & $\$ 7.58 \mathrm{~B}$ & $24.0 \%$ & 75 & $11.6 \%$ \\
\hline 1999 & 46 & $\$ 40.25 \mathrm{~B}$ & 741 & $\$ 8.31 \mathrm{~B}$ & $20.6 \%$ & 73 & $9.9 \%$ \\
\hline 2000 & 39 & $\$ 46.85 \mathrm{~B}$ & 795 & $\$ 10.26 \mathrm{~B}$ & $21.9 \%$ & 70 & $8.8 \%$ \\
\hline 2001 & 36 & $\$ 53.16 \mathrm{~B}$ & 855 & $\$ 11.42 \mathrm{~B}$ & $21.5 \%$ & 98 & $11.5 \%$ \\
\hline 2002 & 33 & $\$ 53.10 \mathrm{~B}$ & 858 & $\$ 12.44 \mathrm{~B}$ & $23.4 \%$ & 112 & $13.1 \%$ \\
\hline 2003 & 31 & $\$ 66.49 \mathrm{~B}$ & 1077 & $\$ 15.80 \mathrm{~B}$ & $23.8 \%$ & 154 & $14.3 \%$ \\
\hline 2004 & 30 & $\$ 66.85 \mathrm{~B}$ & 1139 & $\$ 17.72 B$ & $26.5 \%$ & 293 & $25.7 \%$ \\
\hline $\begin{array}{l}\text { 1991- } \\
2004\end{array}$ & 492 & \$453.31B & 8158 & \$107.61B & $23.7 \%$ & 1164 & $14.3 \%$ \\
\hline
\end{tabular}

(1) Percentage by value $=$ value of fractional interests as a percentage of total LPT portfolio value

(2) Percentage by number of properties $=$ number of fractional interests as a percentage of total number of properties in LPT portfolio

Source: Authors' compilation from PIR (2004a)

While the highest level of fractional interests occurred in 1995 (29.8\% by value of properties), the level of fractional interests, both by value and number of properties, has increased significantly over 1999-2004; with the current level of fractional interests being valued at $\$ 17.72$ billion (26.5\% of LPT portfolio by value of properties) and comprising 293 fractional interest properties (25.7\% of LPT portfolio by number of properties). Major contributing factors to the decline in fractional interests over 1995-1999 were the significant growth in LPTs (from 36 to 50 LPTs) and to the subsequent increase in fractional interests over 1999-2004 from the increased role of international property in 
LPT portfolios, which currently accounts for $29 \%$ of the value of LPT portfolios (Garing et al, 2004). This has seen the number of fractional interests in LPT portfolios increase from only 73 properties in 1999 to 293 properties in 2004.

These levels of fractional interests for Australian LPTs are significantly above those seen for US REITs; being $12.5 \%$ by value of properties and $13.7 \%$ by number of properties in 2002 (Hess and Liang, 2004). This reflects the increased priority for international property investment by LPTs in recent years, resulting from LPTs owning 49\% of institutionalgrade property in Australia (Garing et al, 2004) and seeking international properties (eg: US retail and industrial) for enhanced property portfolio performance opportunities (Murdoch, 2004).

\section{Local versus international fractional interests}

The levels of local and international fractional interests in LPT portfolios over 1991-2004 by value and number of properties are given in Tables 3 and 4 respectively. This has seen the value of fractional interests in LPT portfolios increase from $16.9 \%$ in 1991 to $26.5 \%$ in 2004 (see Table 3) and the number of fractional interests in LPT portfolios increase from $13.9 \%$ in 1991 to $25.7 \%$ in 2004 (see Table 4).

As well as increases in the level of local fractional interests, the major contributing factor to the growth in the LPT fractional interest profile has been the significant increase in international fractional interests since 1996, representing 7.6\% of the total LPT portfolio value and $15.2 \%$ of the total LPT portfolio number of properties in 2004.

This significant increase in international fractional interests in recent years has seen the local contribution to LPT fractional interests steadily decreasing from approximately $100 \%$ up to 1995 to only $71 \%$ by value of properties (see Table 3 ) and $41 \%$ by number of properties (see Table 4) in 2004. This reflects the significant international fractional interests by LPTs such as Macquarie Prologis, Macquarie DDR, Westfield and DB RREEF in the last two years. The use of fractional interests for international properties via a joint venture with an overseas property company was clearly seen as the most effective risk management strategy as confirmed in previous surveys of LPTs (Murdoch, 2004) and LPTs/Asian property investors (Newell and Worzala, 1995). This reflects the desire by the LPT to have access to local expertise and market knowledge, with the local partner also providing the day-to-day functions (eg: property management) while the LPT deals with debt and capital management (Murdoch, 2004).

As seen in Tables 3 and 4, when benchmarked against the 100\%-owned LPT properties, the level of international fractional interests is significantly above the equivalent level of international property that is $100 \%$-owned by LPTs. For example, in 2004, international fractional interests accounted for $29 \%$ of the value of all LPT fractional interests, whereas international property only accounted for $4 \%$ of the value of properties owned $100 \%$ by LPTs (see Table 3). Similarly, in 2004, international fractional interests accounted for 
$26 \%$ of the number of all LPT fractional interest properties, whereas international property only accounted for $4 \%$ of the number of properties owned $100 \%$ by LPTs (see Table 4). This trend has become increasingly evident since 1999 as LPTs have enhanced their international property portfolios, particularly in the US via fractional interest property investments.

Table 3: Local versus international fractional interests (by value of properties): 1991-2004 ${ }^{(1)}$

\begin{tabular}{|c|c|c|c|c|c|}
\hline Year & $\begin{array}{c}\text { Local } \\
\text { fractional } \\
\text { interests } \\
(\%) \\
\end{array}$ & $\begin{array}{c}\text { International } \\
\text { fractional } \\
\text { interests } \\
(\%) \\
\end{array}$ & $\begin{array}{c}\text { Total } \\
\text { fractional } \\
\text { interests } \\
(\%) \\
\end{array}$ & $\begin{array}{c}\% \text { local FI } \\
\text { in total FIs }\end{array}$ & $\begin{array}{c}\text { \% local of } \\
100 \% \\
\text { ownership in } \\
\text { LPT portfolio }\end{array}$ \\
\hline 1991 & $16.9 \%$ & $0.0 \%$ & $16.9 \%$ & $100 \%$ & $97 \%$ \\
\hline 1992 & $20.1 \%$ & $0.0 \%$ & $20.1 \%$ & $100 \%$ & $96 \%$ \\
\hline 1993 & $27.9 \%$ & $0.0 \%$ & $27.9 \%$ & $100 \%$ & $97 \%$ \\
\hline 1994 & $27.9 \%$ & $0.4 \%$ & $28.3 \%$ & $99 \%$ & $98 \%$ \\
\hline 1995 & $29.8 \%$ & $0.1 \%$ & $29.8 \%$ & $99 \%$ & $96 \%$ \\
\hline 1996 & $22.9 \%$ & $2.5 \%$ & $25.4 \%$ & $90 \%$ & $85 \%$ \\
\hline 1997 & $22.8 \%$ & $1.8 \%$ & $24.6 \%$ & $93 \%$ & $86 \%$ \\
\hline 1998 & $22.1 \%$ & $1.9 \%$ & $24.0 \%$ & $92 \%$ & $87 \%$ \\
\hline 1999 & $15.5 \%$ & $5.1 \%$ & $20.6 \%$ & $75 \%$ & $85 \%$ \\
\hline 2000 & $17.9 \%$ & $4.0 \%$ & $21.9 \%$ & $82 \%$ & $81 \%$ \\
\hline 2001 & $17.3 \%$ & $4.2 \%$ & $21.5 \%$ & $80 \%$ & $78 \%$ \\
\hline 2002 & $19.6 \%$ & $3.8 \%$ & $23.4 \%$ & $84 \%$ & $82 \%$ \\
\hline 2003 & $17.1 \%$ & $6.7 \%$ & $23.8 \%$ & $72 \%$ & $74 \%$ \\
\hline 2004 & $18.9 \%$ & $7.6 \%$ & $26.5 \%$ & $71 \%$ & $96 \%$ \\
\hline $\begin{array}{l}1991- \\
2004\end{array}$ & $19.5 \%$ & $4.2 \%$ & $23.7 \%$ & $82 \%$ & $85 \%$ \\
\hline
\end{tabular}

(1) Percentages represent percentage of value of total LPT property portfolio 
Table 4: Local versus international fractional interests (by number of properties): 1991-2004 ${ }^{(1)}$

\begin{tabular}{|c|c|c|c|c|c|}
\hline Year & $\begin{array}{c}\text { Local } \\
\text { fractional } \\
\text { interests } \\
(\%) \\
\end{array}$ & $\begin{array}{c}\text { International } \\
\text { fractional } \\
\text { interests } \\
(\%) \\
\end{array}$ & $\begin{array}{c}\text { Total } \\
\text { fractional } \\
\text { interests } \\
(\%) \\
\end{array}$ & $\begin{array}{c}\text { \% local FI } \\
\text { in total FIs }\end{array}$ & $\begin{array}{c}\text { \% local of } \\
100 \% \\
\text { ownership in } \\
\text { LPT portfolio } \\
\end{array}$ \\
\hline 1991 & $13.9 \%$ & $0.0 \%$ & $13.9 \%$ & $100 \%$ & $93 \%$ \\
\hline 1992 & $13.0 \%$ & $0.0 \%$ & $13.0 \%$ & $100 \%$ & $94 \%$ \\
\hline 1993 & $15.5 \%$ & $0.0 \%$ & $15.5 \%$ & $100 \%$ & $95 \%$ \\
\hline 1994 & $16.8 \%$ & $0.4 \%$ & $17.2 \%$ & $98 \%$ & $96 \%$ \\
\hline 1995 & $15.8 \%$ & $0.3 \%$ & $16.2 \%$ & $98 \%$ & $93 \%$ \\
\hline 1996 & $12.0 \%$ & $2.0 \%$ & $14.1 \%$ & $85 \%$ & $90 \%$ \\
\hline 1997 & $10.6 \%$ & $1.1 \%$ & $11.7 \%$ & $90 \%$ & $92 \%$ \\
\hline 1998 & $10.5 \%$ & $1.1 \%$ & $11.6 \%$ & $91 \%$ & $97 \%$ \\
\hline 1999 & $8.1 \%$ & $1.8 \%$ & $9.9 \%$ & $82 \%$ & $95 \%$ \\
\hline 2000 & $7.4 \%$ & $1.4 \%$ & $8.8 \%$ & $84 \%$ & $95 \%$ \\
\hline 2001 & $9.8 \%$ & $1.6 \%$ & $11.5 \%$ & $86 \%$ & $92 \%$ \\
\hline 2002 & $10.1 \%$ & $2.9 \%$ & $13.1 \%$ & $78 \%$ & $91 \%$ \\
\hline 2003 & $10.2 \%$ & $4.1 \%$ & $14.3 \%$ & $71 \%$ & $82 \%$ \\
\hline 2004 & $10.5 \%$ & $15.2 \%$ & $25.7 \%$ & $41 \%$ & $96 \%$ \\
\hline $\begin{array}{l}1991- \\
2004\end{array}$ & $10.6 \%$ & $3.7 \%$ & $14.3 \%$ & $74 \%$ & $92 \%$ \\
\hline
\end{tabular}

(1) Percentages represent percentage of total number of properties in LPT property portfolio

\section{Role of specific LPTs}

Table 5 presents the LPTs with significant fractional interest portfolios in 2004, with $73 \%$ of the LPTs assessed having fractional interests in their property portfolios. At $100 \%$ international fractional interests, Macquarie Prologis and Macquarie DDR reinforce the joint venture strategy as the most effective international risk management strategy. Other LPTs to effectively implement this international strategy of having a significant number of 
international fractional interests in their property portfolio include DB RREEF (53\% of total portfolio), Westfield ( $15 \%$ of total portfolio), Galileo ( $27 \%$ of total portfolio), Macquarie CountryWide (18\% of total portfolio) and Macquarie Office (24\% of total portfolio). In particular, the joint venture partners were Prologis (Macquarie Prologis), DDR (Macquarie DDR), DB RREEF Operations Trust (DB RREEF), Simon Properties (Westfield), CBL Properties (Galileo) and Regency Centres (Macquarie CountryWide); all being significant US property players, particularly in retail and industrial property.

Fractional interests are also significant for a range of LPTs with substantial local fractional interest portfolios in their total fractional interest portfolios; this includes Ronin ( $70 \%$ of total portfolio), Centro (43\% of total portfolio), James Fielding (33\% of total portfolio), Investa (31\% of total portfolio) and JF Meridian (31\% of total portfolio), with James Fielding, Investa and JF Meridian having 100\% local fractional interests in their total fractional interest portfolio. Other LPTs with significant $100 \%$ local fractional interests include Commonwealth Office (23\% of total portfolio), Gandel Retail (23\% of total portfolio), Multiplex (19\% of total portfolio) and Macquarie Goodman Industrial (17\% of total portfolio). Leading LPTs also have significant fractional interest portfolios; namely GPT (15\% of total portfolio) and Stockland (10\% of total portfolio); these being $100 \%$ local fractional interests.

Table 6 presents the major LPT fractional interest commercial properties (by value) in 2004. The risk management strategy to acquire more expensive properties via fractional interests is clearly evident for both the local and international markets. The success of this strategy to use fractional interests in acquiring landmark properties, particularly in the Sydney CBD office market, is reflected in significant landmark properties such as the Governor Phillip Tower, Darling Park Complex, Citigroup Centre and MLC Centre being structured as fractional interests by DB RREEF, GPT and Macquarie Office Trust. These $50 \%$ fractional interests ranged from $\$ 285$ million to $\$ 478$ million. This strategy effectively manages the impact of single-asset risk in their LPT property portfolios. Similarly, fractional interests have seen the acquiring of significant retail properties. Examples of significant local retail fractional interests include the Chadstone Shopping Centre (50\% interest@ @ \$644 million by CFS Gandel Retail Trust) and significant international retail fractional interests include the Garden State Plaza (75\% interest @ \$624 million by Westfield). 
Table 5: Leading LPTs with fractional interests (by number of properties): 2004

\begin{tabular}{|c|c|c|c|c|c|c|c|}
\hline \multirow[b]{2}{*}{ LPT } & \multirow[b]{2}{*}{$\begin{array}{c}\text { Total } \\
\text { number of } \\
\text { properties } \\
\text { in portfolio }\end{array}$} & \multicolumn{6}{|c|}{ Level of fractional interests } \\
\hline & & $\begin{array}{c}\text { Total } \\
\text { number of } \\
\text { fractional } \\
\text { interests in } \\
\text { portfolio }\end{array}$ & $\begin{array}{l}\text { Total } \\
(\%)\end{array}$ & $\begin{array}{c}\text { Number } \\
\text { of local } \\
\text { fractional } \\
\text { interests }\end{array}$ & $\begin{array}{c}\text { Local } \\
\text { FI } \\
(\%)\end{array}$ & $\begin{array}{c}\text { Number } \\
\text { of } \\
\text { internat. } \\
\text { fractional } \\
\text { interests }\end{array}$ & $\begin{array}{c}\text { Internat. } \\
\text { FI } \\
(\%)\end{array}$ \\
\hline $\begin{array}{c}\text { Macquarie } \\
\text { Prologis }\end{array}$ & 101 & 101 & $100 \%$ & 0 & $0 \%$ & 101 & $100 \%$ \\
\hline $\begin{array}{l}\text { Macquarie } \\
\text { DDR }\end{array}$ & 22 & 22 & $100 \%$ & 0 & $0 \%$ & 22 & $100 \%$ \\
\hline Ronin & 23 & 16 & $70 \%$ & 5 & $22 \%$ & 11 & $48 \%$ \\
\hline DB RREEF & 172 & 104 & $60 \%$ & 12 & $7 \%$ & 92 & $53 \%$ \\
\hline Centro & 67 & 29 & $43 \%$ & 15 & $22 \%$ & 14 & $21 \%$ \\
\hline $\begin{array}{l}\text { James } \\
\text { Fielding }\end{array}$ & 9 & 3 & $33 \%$ & 3 & $33 \%$ & 0 & $0 \%$ \\
\hline Investa & 39 & 12 & $31 \%$ & 12 & $31 \%$ & 0 & $0 \%$ \\
\hline $\begin{array}{l}\text { J F } \\
\text { Meridian }\end{array}$ & 29 & 9 & $31 \%$ & 9 & $31 \%$ & 0 & $0 \%$ \\
\hline Westfield & 125 & 38 & $30 \%$ & 19 & $15 \%$ & 19 & $15 \%$ \\
\hline $\begin{array}{l}\text { Macquarie } \\
\text { Office }\end{array}$ & 33 & 10 & $30 \%$ & 2 & $6 \%$ & 8 & $24 \%$ \\
\hline Valad & 7 & 2 & $29 \%$ & 2 & $29 \%$ & 0 & $0 \%$ \\
\hline Galileo & 45 & 12 & $27 \%$ & 0 & $0 \%$ & 12 & $27 \%$ \\
\hline $\begin{array}{l}\text { Common- } \\
\text { wealth } \\
\text { Office }\end{array}$ & 26 & 6 & $23 \%$ & 6 & $23 \%$ & 0 & $0 \%$ \\
\hline $\begin{array}{l}\text { Gandel } \\
\text { Retail }\end{array}$ & 22 & 5 & $23 \%$ & 5 & $23 \%$ & 0 & $0 \%$ \\
\hline Multiplex & 21 & 4 & $19 \%$ & 4 & $19 \%$ & 0 & $0 \%$ \\
\hline $\begin{array}{l}\text { Macquarie } \\
\text { Country- } \\
\text { Wide }\end{array}$ & 112 & 20 & $18 \%$ & 0 & $0 \%$ & 20 & $18 \%$ \\
\hline $\begin{array}{l}\text { Macquarie } \\
\text { Goodman } \\
\text { Industrial }\end{array}$ & 139 & 23 & $17 \%$ & 23 & $17 \%$ & 0 & $0 \%$ \\
\hline GPT & 78 & 12 & $15 \%$ & 12 & $15 \%$ & 0 & $0 \%$ \\
\hline ING Office & 24 & 3 & $13 \%$ & 3 & $13 \%$ & 0 & $0 \%$ \\
\hline Stockland & 102 & 10 & $10 \%$ & 10 & $10 \%$ & 0 & $0 \%$ \\
\hline
\end{tabular}

Source: Authors' compilation from PIR (2004a) 
Table 6: Major LPT fractional interest commercial properties: $2004^{(1)(2)}$

\section{Retail}

Chadstone Shopping Centre (Vic): CFS Gandel Retail Trust: 50\%: \$644 million

Garden State Plaza (New Jersey, US): Westfield: 75\%: \$624 million

Westfield Miranda (NSW): Westfield: 50\%: \$417 million

Mission Valley Centre (San Diego, US): Westfield: 75\%: \$411 million

Garden City Mt Gravatt (Qld): Westfield: 50\%: \$393 million

Valley Fair (San Jose, US): Westfield: 50\%: \$373 million

Westfield Southland (Vic.): Westfield: 50\%: \$361 million

Westfield Marion (SA): Westfield: 50\%: \$323 million

Pacific Fair (Qld): Westfield: 40\%: \$289 million

Macquarie Centre (NSW): Westfield: 50\%: \$282 million

Montgomery Mall (Bethesda, US): Westfield: 50\%: \$244 million

\section{Office}

Governor Phillip Tower (NSW): DB RREEF: 50\%: \$478 million

Darling Park Complex (NSW): GPT: 50\%: \$459 million

Citigroup Centre (NSW): Macquarie Office Trust: 50\%: \$288 million

Citigroup Centre (NSW): GPT: 50\%: \$288 million

MLC Centre (NSW): GPT: 50\%: \$285 million

Darling Park Complex (NSW): Ronin: 30\%: \$276 million

Exchange Centre (NSW): ING Office Trust: 50\%: \$248 million

(1) US\$1=AUD $1.45 @$ June 2004

(2) Value cited is for LPT fractional interest only

Source: PIR (2004a)

Of these eighteen fractional interest properties shown in Table 6, retail property was the most significant component (61\% of properties). Amongst these eleven major retail fractional interest properties, $64 \%$ of properties were local fractional interests, with Westfield accounting for $91 \%$ of these major retail fractional interests $(55 \%$ local and $36 \%$ international). A 50\%:50\% fractional interest ownership structure was clearly the preferred retail option, accounting for $91 \%$ of these retail fractional interest properties, reflecting the need for balancing the issues of affordability and control (Hess and Liang, 2004). Of the seven leading office property fractional interests, $100 \%$ were local fractional 
interests, with GPT accounting for $43 \%$ of these major fractional interests and the $50 \%: 50 \%$ ownership structure being evident in $86 \%$ of cases for these office fractional interest properties.

\section{Significance of property type in fractional interests}

Table 7 presents the fractional interest profile by property type in LPTs over 1991-2004. Retail property dominates both the local and international fractional interests, representing $64.2 \%$ by value of properties and $56.4 \%$ by number of properties for fractional interests over this 14-year period. This level of fractional interest retail property is significantly above the level of retail property (53\% and 38\% respectively) that is $100 \%$-owned by LPTs. Retail property has always dominated the LPT fractional interest property profile over this period, representing $55-78 \%$ by value of properties and $42-67 \%$ by number of properties each year; with these levels having dropped slightly in the last four years. The significant role of Westfield and Gandel, and more recently by Macquarie DDR , Macquarie CountryWide and Galileo are clearly evident in this retail fractional interest exposure; particularly reflecting significant fractional interests in US retail property.

Industrial property has taken a more significant role in fractional interests over 2003-04; particularly for international fractional interests which account for $44 \%$ by value of properties and $66 \%$ by number of properties for these industrial fractional interests. This clearly reflects the significant level of US industrial fractional interests in Macquarie Prologis (see Table 5). While industrial fractional interests are increasing, the level of industrial fractional interests $(3.1 \%$ by value of properties and $13.1 \%$ by number of properties) are significantly below the level of industrial property that is $100 \%$-owned by LPTs $(11.0 \%$ and $30.5 \%$ respectively). This largely reflects the less expensive industrial property sector, which enables a $100 \%$ ownership strategy for industrial property to be effectively utilised locally by LPTs.

Office property represents $33 \%$ of fractional interests by value, being predominantly local fractional interests $(74 \%$ by value of fractional interest office properties and $92 \%$ by number of fractional interest office properties), with a leading role by DB RREEF, GPT and Macquarie Office. The level of office fractional interests is comparable to the levels of office property that is $100 \%$-owned by LPTs.

Overall, fractional interests have proven to be an effective risk management strategy for accessing quality international retail and industrial property via a joint venture structure, as well as accessing landmark local office properties, particularly in the Sydney CBD office market. 
Table 7: Fractional interest profile by property type: 1991-2004 ${ }^{(1)}$

\begin{tabular}{|c|c|c|c|c|c|c|}
\hline $\begin{array}{l}\text { By value of } \\
\text { properties: }\end{array}$ & $\begin{array}{c}\text { Local } \\
\text { fractional } \\
\text { interests } \\
(\%)\end{array}$ & $\begin{array}{c}\text { Internat. } \\
\text { fractional } \\
\text { interests } \\
(\%)\end{array}$ & $\begin{array}{c}\text { Total } \\
\text { fractional } \\
\text { interests } \\
(\%)\end{array}$ & $\begin{array}{c}\% \\
\text { local } \\
\text { FI }\end{array}$ & $\begin{array}{c}\text { Percentage } \\
\text { of total FI }\end{array}$ & $\begin{array}{c}\text { Percentage } \\
\text { of } 100 \% \\
\text { ownership in } \\
\text { LPT } \\
\text { portfolio } \\
\end{array}$ \\
\hline Office & $7.4 \%$ & $0.5 \%$ & $7.9 \%$ & $94 \%$ & $33.1 \%$ & $31.5 \%$ \\
\hline Retail & $11.6 \%$ & $3.6 \%$ & $15.2 \%$ & $76 \%$ & $64.2 \%$ & $53.5 \%$ \\
\hline Industrial & $0.3 \%$ & $0.2 \%$ & $0.5 \%$ & $56 \%$ & $2.1 \%$ & $11.0 \%$ \\
\hline Hotel & $0.1 \%$ & $0.0 \%$ & $0.1 \%$ & $100 \%$ & $0.3 \%$ & $2.8 \%$ \\
\hline Other & $0.1 \%$ & $0.0 \%$ & $0.1 \%$ & $100 \%$ & $0.3 \%$ & $1.2 \%$ \\
\hline Total & $19.5 \%$ & $4.2 \%$ & $23.7 \%$ & $82 \%$ & $100.0 \%$ & $100.0 \%$ \\
\hline $\begin{array}{l}\text { By number of } \\
\text { properties: }\end{array}$ & $\begin{array}{c}\text { Local } \\
\text { fractional } \\
\text { interests } \\
(\%)\end{array}$ & $\begin{array}{c}\text { Internat. } \\
\text { fractional } \\
\text { interests } \\
(\%)\end{array}$ & $\begin{array}{c}\text { Total } \\
\text { fractional } \\
\text { interests } \\
(\%)\end{array}$ & $\begin{array}{c}\% \\
\text { local } \\
\text { FI }\end{array}$ & $\begin{array}{c}\text { Percentage } \\
\text { of total FI }\end{array}$ & $\begin{array}{c}\text { Percentage } \\
\text { of } 100 \% \\
\text { ownership } \\
\text { in LPT } \\
\text { portfolio } \\
\end{array}$ \\
\hline Office & $3.9 \%$ & $0.3 \%$ & $4.2 \%$ & $92 \%$ & $29.6 \%$ & $27.2 \%$ \\
\hline Retail & $5.9 \%$ & $2.1 \%$ & $8.0 \%$ & $73 \%$ & $56.4 \%$ & $38.0 \%$ \\
\hline Industrial & $0.6 \%$ & $1.2 \%$ & $1.8 \%$ & $34 \%$ & $13.1 \%$ & $30.5 \%$ \\
\hline Hotel & $0.1 \%$ & $0.0 \%$ & $0.1 \%$ & $100 \%$ & $0.1 \%$ & $2.1 \%$ \\
\hline Other & $0.1 \%$ & $0.0 \%$ & $0.1 \%$ & $100 \%$ & $0.6 \%$ & $2.2 \%$ \\
\hline Total & $10.6 \%$ & $3.7 \%$ & $14.3 \%$ & $74 \%$ & $100.0 \%$ & $100.0 \%$ \\
\hline
\end{tabular}

(1) Percentages represent percentage of total LPT property portfolio

\section{Significance of ownership structure in fractional interests}

Ownership structure is the key factor in fractional interests and reflects the level of management control over the ongoing operation of the property. Table 8 indicates the ownership structure for fractional interests in LPTs over 1991-2004. 50\%:50\% is clearly the preferred ownership structure, accounting for $72.5 \%$ by value of fractional interest properties and $59.2 \%$ by number of fractional interest properties over this period. 
Table 8: Fractional interest profile by ownership structure: $1991-2004^{(1)}$

\begin{tabular}{|c|c|c|c|c|c|}
\hline $\begin{array}{l}\text { By value of } \\
\text { properties: }\end{array}$ & $\begin{array}{c}\text { Local } \\
\text { fractional } \\
\text { interests } \\
(\%) \\
\end{array}$ & $\begin{array}{c}\text { Internat. } \\
\text { fractional } \\
\text { interests } \\
(\%) \\
\end{array}$ & $\begin{array}{c}\text { Total } \\
\text { fractional } \\
\text { interests } \\
(\%) \\
\end{array}$ & $\begin{array}{c}\text { \% local } \\
\text { FI }\end{array}$ & $\begin{array}{l}\text { Percentage } \\
\text { of total FI }\end{array}$ \\
\hline $50 \%$ & $15.5 \%$ & $1.7 \%$ & $16.2 \%$ & $90 \%$ & $72.5 \%$ \\
\hline$<50 \%$ & $3.1 \%$ & $0.7 \%$ & $3.8 \%$ & $83 \%$ & $15.9 \%$ \\
\hline$>50 \%$ & $0.9 \%$ & $1.9 \%$ & $2.8 \%$ & $31 \%$ & $11.6 \%$ \\
\hline Total & $19.5 \%$ & $4.2 \%$ & $23.7 \%$ & $82 \%$ & $100.0 \%$ \\
\hline $\begin{array}{l}\text { By } \\
\text { number of } \\
\text { properties: }\end{array}$ & $\begin{array}{c}\text { Local } \\
\text { fractional } \\
\text { interests } \\
(\%)\end{array}$ & $\begin{array}{c}\text { Internat. } \\
\text { fractional } \\
\text { interests } \\
(\%)\end{array}$ & $\begin{array}{c}\text { Total } \\
\text { fractional } \\
\text { interests } \\
(\%) \\
\end{array}$ & $\begin{array}{c}\% \text { local } \\
\text { FI }\end{array}$ & $\begin{array}{l}\text { Percentage } \\
\text { of total FI }\end{array}$ \\
\hline $50 \%$ & $7.7 \%$ & $0.7 \%$ & $8.4 \%$ & $91 \%$ & $59.2 \%$ \\
\hline$<50 \%$ & $1.8 \%$ & $0.5 \%$ & $2.3 \%$ & $80 \%$ & $15.5 \%$ \\
\hline$>50 \%$ & $1.1 \%$ & $2.5 \%$ & $3.6 \%$ & $30 \%$ & $25.3 \%$ \\
\hline Total & $10.6 \%$ & $3.7 \%$ & $14.3 \%$ & $74 \%$ & $100.0 \%$ \\
\hline
\end{tabular}

(1) Percentages represent percentage of total LPT property portfolio

Local fractional interests were predominantly a 50\%:50\% ownership structure; particularly for the higher value office and retail properties. However, for international fractional interests, more importance was given to a greater than $50 \%$ fractional interest ownership structure, with the local partner often largely providing local management expertise rather than an equal share of ownership. This preference for greater than $50 \%$ fractional interest ownership structure by LPTs for international properties reflects the need for management control; particularly given the significant debt and capital management responsibilities undertaken by the LPTs for these international properties.

Typical of this greater than $50 \%$ ownership in the international fractional interest is evidenced in the DB RREEF portfolio (most at $80 \%$ ownership), Macquarie Prologis portfolio (most at $89 \%$ ownership), Macquarie DDR portfolio (most at $82 \%$ ownership) and Macquarie CountryWide portfolio (most at $75 \%$ ownership). This trend to greater than $50 \%$ ownership in the fractional interest has been particularly evident since 2003 , with the increased LPT focus on acquiring international properties via fractional interests. 
For example, in 2004, greater than $50 \%$ fractional interest accounted for $24 \%$ of all fractional interests by value of these fractional interest properties; this being double the average figure for the full period of 1991-2004.

An important legal consideration regarding the co-ownership structure for fractional interests relates to the disposal of the asset. Often these fractional interests are structured so that the other party in the co-ownership arrangement has the first right over the property; particularly if one of the co-owners is involved in a hostile take-over.

\section{CONCLUSION}

By assessing the ownership structure and details of over 8,500 commercial properties in the LPT property portfolios over 1991-2004, fractional interests have been shown to be significant components in these LPT portfolios, accounting for $23.7 \%$ by value for these LPT properties and $14.3 \%$ by number of these LPT properties over this period. Importantly, the level of fractional interests has increased over the last five years, both in the local and international LPT property portfolios.

Fractional interests have clearly been an effective risk management strategy to manage single-asset risk in the LPT property portfolios. Importantly, it has enabled LPTs to acquire local landmark office and retail properties, whilst still retaining a significant degree of management control over the property asset via a typical 50\%:50\% ownership structure for the fractional interest. Similarly, it has enabled LPTs to acquire significant international properties, particularly US retail and industrial properties, whilst still retaining management control of the property asset, typically using a more than $50 \%$ ownership structure for the property via a joint venture with a local player in the specific international property market.

The need for quality local and international property assets in LPT property portfolios will take on increased importance in the future, as LPTs enhance their dominant role as the leading property investment vehicle in Australia. As such, fractional interests will continue to play an increasing role in LPT property portfolios, as LPT fund managers seek to manage single-asset risk in acquiring landmark property assets and also seek to retain a high degree of management control over the property asset using a 50\%:50\% ownership structure or greater than $50 \%$ ownership structure for international properties.

Ongoing issues concerning LPT fractional interests that will require further research include:

- performance of fractional interest properties versus $100 \%$-owned properties

- performance of local versus international fractional interests

- effectiveness of fractional interest ownership structures

- effectiveness of fractional interests in non-US international markets

- utilisation of fractional interests by other property investment vehicles. 
These areas of research will become particularly important as fractional interests become an increasingly common property investment ownership structure for Australian LPTs.

\section{REFERENCES}

Donaldson, B. (1994), At what price liquidity? Real Estate Finance (Fall): 33-39.

Fife, A. (2003), Valuation of fractional interests. Australian Property Journal 37(5): 360362.

Fife, A. and Newell, G. (1995), The valuation of fractional interests. The Valuer and Land Economist 33(6): 467-469.

Garing, S., Hoog Antink, V., Kivell, D. and Rampa, K. (2004), Market frontiers: capital markets. Proceedings of 2004 PCA Congress. PCA, Sydney.

Hanford, L. (1989), The market value of partial interests in real property. The Appraisal Journal (Oct): 460-465.

Hess, R. and Liang, Y. (2004), REIT joint venture use is on the rise. Journal of Real Estate Portfolio Management 10(1): 77-84.

Humphrey, W. and Humphrey, B. (1997), Unsyndicated partial interest discounting. The Appraisal Journal (July): 267-274.

Ludgin, M. and Ingall, L. (2004), Nothing ventured, nothing gained: the risk of real estate joint ventures. NCREIF Quarterly Report (Q1): 2-3.

Murdoch, J. (2004), The globalisation of Australian LPTs. Australian Property Journal 38(1): 5-12.

Newell, G. and Acheampong, P. (2001), The dynamics of the Australian LPT market risk and correlation profile. Pacific Rim Property Research Journal 7(4): 259-270.

Newell, G. and Tan, Y.K. (2003), The significance of property sector and geographic diversification in Australian institutional property portfolios. Pacific Rim Property Research Journal 9(3): 248-264.

Newell, G. and Worzala, E. (1995), The role of international property in investment portfolios. Journal of Property Finance 6(1): 55-63.

Property Council of Australia. (2004), Investment Performance Index: June 2004. PCA, Sydney. 
Property Investment Research. (2004a), Annual Property Trust Review 2004 (and miscellaneous previous copies). PIR, Melbourne.

Property Investment Research. (2004b), Australian Property Funds Industry Survey 2004. PIR, Melbourne.

Thompson, M. and Dagbjartsson, E. (1994), Market discounting of partial ownership interests. The Appraisal Journal (Oct): 535-541.

UBS. (2005), UBS Indices: January 2005 (and miscellaneous previous copies). UBS, Sydney.

Wiggins, D. and Rosenberg, S. (2001), Revisiting valuation of real estate partial interests: recent case studies. The Appraisal Journal (Oct): 404-409.

Wilson, P. and Okunev, J. (1996), Evidence of segmentation in domestic and international property markets. Journal of Property Finance 7(1): 78-97.

Wilson, P. and Okunev, J. (1999), Long-term dependencies and long-run non-periodic cocycles: real estate and stockmarkets. Journal of Real Estate Research 18(2): 257-278.

Wilson, P., Okunev, J. and Webb, J. (1998), Step interventions and market integration: tests in the US, UK and Australian property markets. Journal of Real Estate Finance and Economics 16(2): 91-123. 